\title{
Functional Differentiation in the Leucine-Rich Repeat Domains of Closely Related Plant Virus-Resistance Proteins That Recognize Common Avr Proteins
}

\author{
Ken-Taro Sekine, ${ }^{1}$ Reiko Tomita, ${ }^{1}$ Shigeharu Takeuchi, ${ }^{2}$ Go Atsumi, ${ }^{1}$ Hiromasa Saitoh, ${ }^{1}$ \\ Hiroyuki Mizumoto, ${ }^{3}$ Akinori Kiba, ${ }^{3}$ Naoto Yamaoka, ${ }^{4}$ Masamichi Nishiguchi, ${ }^{4}$ Yasufumi Hikichi, ${ }^{3}$ \\ and Kappei Kobayashi ${ }^{4}$
} 'Iwate Biotechnology Research Center, Kitakami 024-0003, Iwate, Japan; ${ }^{2}$ Laboratory of Plant Pathology, Kochi Agricultural
Research Center, Nankoku, Kochi 783-0023, Japan; ${ }^{3}$ Laboratory of Plant Pathology \& Biotechnology, Kochi University,
Nankoku, Kochi 783-8502, Japan; ${ }^{4}$ Faculty of Agriculture, Ehime University, Matsuyama, Ehime 790-8566, Japan

Submitted 15 November 2011. Accepted 23 May 2012.

\begin{abstract}
The $N^{\prime}$ gene of Nicotiana sylvestris and $L$ genes of Capsicum plants confer the resistance response accompanying the hypersensitive response (HR) elicited by tobamovirus coat proteins (CP) but with different viral specificities. Here, we report the identification of the $N^{\prime}$ gene. We amplified and cloned an $N^{\prime}$ candidate using polymerase chain reaction primers designed from $L$ gene sequences. The $N^{\prime}$ candidate gene was a single 4143 base pairs fragment encoding a coiled-coil nucleotide-binding leucine-rich repeat (LRR)type resistance protein of 1,380 amino acids. The candidate gene induced the $H R$ in response to the coexpression of tobamovirus $\mathrm{CP}$ with the identical specificity as reported for $N^{\prime}$. Analysis of $N^{\prime}$-containing and tobamovirus-susceptible $N$. tabacum accessions supported the hypothesis that the candidate is the $N^{\prime}$ gene itself. Chimera analysis between $N^{\prime}$ and $L^{3}$ revealed that their LRR domains determine the spectrum of their tobamovirus $C P$ recognition. Deletion and mutation analyses of $N^{\prime}$ and $L^{3}$ revealed that the conserved sequences in their $\mathrm{C}$-terminal regions have important roles but contribute differentially to the recognition of common avirulence proteins. The results collectively suggest that Nicotiana $N^{\prime}$ and Capsicum $L$ genes, which most likely evolved from a common ancestor, differentiated in their recognition specificity through changes in the structural requirements for $L R R$ function.
\end{abstract}

The use of plant resistance $(R)$ genes to breed resistant crops continues to be an effective strategy for maintaining crop yield. An $R$ gene confers effector-triggered immunity (ETI; formerly termed gene-for-gene resistance) to a specific pathogen carrying a corresponding avirulence (Avr) effector gene (Flor 1971; Jones and Dangl 2006). ETI is generally associ-

Nucleotide sequence data can be found in the DDBJ, EMBL, and GenBank databases under accession numbers AB669000 for $N^{\prime}$, AB669001 for Nt-n', and AB669002 for the Tobacco mosaic virus K98 coat protein gene.

Corresponding author: K. Kobayashi; E-mail: kappei@agr.ehime-u.ac.jp

* The $\boldsymbol{e}$-Xtra logo stands for "electronic extra" and indicates that ten supplementary figures, one supplementary table, and supplementary methods information are published online and that Figures 1, 3, 4, and 5 appear in color online. ated with lesions of programmed cell death in or around the site of pathogen infection, referred to as the hypersensitive response (HR) (Heath 2000). Understanding the mechanisms by which an $\mathrm{R}$ protein recognizes a pathogen effector, especially the mechanism that determines recognition specificity, can help in the development of new strategies for preventing invasion and the breakdown of useful $R$ genes by quickly evolving pathogens.

During the last few decades, a number of plant $R$ genes have been isolated from model plants and agronomically important crops (Collier and Moffett 2009). The majority of these $R$ genes encode intracellular receptor proteins consisting of three domains: an N-terminal coiled-coil (CC) or Toll interleukin-1 receptor-like (TIR) domain, a nucleotide-binding (NB) domain, and a C-terminal leucine-rich repeat (LRR) domain (Moffett 2009). The NB domain contains a region of homology known as the ApafI, R proteins, and CED4 (ARC) domain that consists of two distinct structural and functional units, ARC1 and ARC2 (Albrecht and Takken 2006; McHale et al. 2006; Rairdan and Moffett 2006; van der Biezen and Jones 1998). The LRR domain is the major determinant for recognition specificity (Banerjee et al. 2001; Dodds et al. 2001; Ellis et al. 2000; Moffett et al. 2002; Rairdan and Moffett 2006; Shen et al. 2003). An LRR domain contains a series of $\beta$-sheets formed by xxLxLxx motifs (where $\mathrm{x}$ and $\mathrm{L}$ are any amino acid and any aliphatic residue, respectively) and forms the concave face of the horseshoe-shaped domain that is involved in protein-protein interactions (Kobe and Kajava 2001; McHale et al. 2006). Additionally, the solventexposed residues of the $\beta$-sheets ( $x$ in the xxLxLxx motif) in the LRR domain determine the recognition specificity of NB-LRR proteins and LRR receptor-like R proteins (McHale et al. 2006).

Several tobamovirus $R$ genes have been identified, cloned, and used for breeding resistant crops. The first cloned tobamovirus $R$ gene was the tobacco $N$ gene encoding a TIR-NBLRR-type R protein that recognizes the helicase domain of Tobacco mosaic virus (TMV) RNA polymerase (Erickson et al. 1999; Whitham et al. 1994). The tomato Tm-2 and Tm-2 genes, encoding CC-NB-LRR-type $\mathrm{R}$ proteins, recognize the movement protein of Tomato mosaic virus (ToMV) as an Avr factor (Lanfermeijer et al. 2003, 2005; Meshi et al. 1989; Weber and Pfitzner 1998). Recently, we used map-based cloning and 
homology-based methods to clone seven $L$ gene alleles from Capsicum spp. that also encode CC-NB-LRR-type R proteins (Tomita et al. 2011).

The $L$ gene alleles $L^{1}$ through $L^{4}$ are numbered in order of their increasing ability to recognize Tobamovirus spp. Correspondingly, tobamoviruses are classified into the pathotypes $\mathrm{P}_{0}, \mathrm{P}_{1}, \mathrm{P}_{1,2}, \mathrm{P}_{1,2,3}$, and $\mathrm{P}_{1,2,3,4}$ based on their ability to infect systemically Capsicum plants carrying different $L$ gene alleles (Boukema 1980, 1982, 1984; Genda et al. 2007). TMV and ToMV are classified into pathotype $\mathrm{P}_{0}$, that can be recognized by all $L$ alleles. Paprika mild mottle virus (PaMMV) and Pepper mild mottle virus (PMMoV) belong to pathotypes $\mathrm{P}_{1}$ and $\mathrm{P}_{1,2}$, respectively. Some strains of $\mathrm{PMMoV}$ with one or a few amino acid substitutions that differ from $\mathrm{P}_{1,2}$ and the ability to overcome $L^{3}$-mediated resistance are classified as pathotype $\mathrm{P}_{1,2,3}$ (Garcia-Luque et al. 1993; Hamada et al. 2007; Tsuda et al. 1998). To date, two strains classified as the $P_{1,2,3,4}$ pathotype of PMMoV have emerged and are anticipated to spread uncontrollably unless the infected plants are strictly monitored and managed because none of the identified $L$ alleles confer resistance to the PMMoV $\mathrm{P}_{1,2,3,4}$ pathotype (Antignus et al. 2008; Genda et al. 2007). As shown in a previous study, elicitation of the resistance mediated by the $L$ alleles requires a functional coat protein (CP) of tobamovirus as the Avr factor (BerzalHerranz et al. 1995; Dardick et al. 1999; de la Cruz et al. 1997; Gilardi et al. 1998, 2004; Tomita et al. 2011; Tsuda et al. 1998).

Like the $L$ gene alleles, the $N^{\prime}$ gene from Nicotiana sylvestris confers resistance to infection by Tobamovirus spp. via recognition of viral CP as Avr factors (Culver and Dawson 1989; Saito et al. 1987, 1989). Although cloning $R$ genes has become a relatively straightforward procedure, especially after the development of next-generation sequencers, the $N^{\prime}$ gene had not been isolated prior to our investigation. The important feature of the $N^{\prime}$ gene is that it recognizes tobamovirus $\mathrm{CP}$, similar to the $L$ gene but with a different recognition spectrum (i.e., $N^{\prime}$ can trigger a resistance response to ToMV, PaMMV, PMMoV, and even pathotype $\mathrm{P}_{1,2,3,4}$, but not to TMV) (Table 1). Cloning and characterization of $N^{\prime}$ would enable us to identify the immutable mechanisms underlying the recognition of specific effectors by different hosts.

Based on their responses to infection with Tobamovirus spp., $\mathrm{N}^{\prime}$ and $\mathrm{L}$ proteins were hypothesized to be structurally similar (Culver 2002). In other words, $N^{\prime}$ might be an ortholog of the pepper $L$ genes. Similarly, $R$ genes sharing common pathogen effectors have been found in different but evolutionarily related plant species (Dangl et al. 1992; Innes et al. 1993; Ronald et al. 1992; Simonich and Innes 1995; Whalen et al. 1991), providing clues about the dynamics of $R$ gene evolution. Soybean Rgpl-b recognizes a Pseudomonas syringae-derived AvrB protein, as does Arabidopsis RPM1, but the soybean $R$ gene has a distinct origin from RPM1 (Ashfield et al. 2004). Thus, RPM1 and Rgp1-b provided the first evidence for the convergent evolution of $R$ gene function. Analysis of the phy- logenic and functional relationships between Capsicum $L$ and Nicotiana $N^{\prime}$ genes led to new strategies for identifying $R$ genes from different plant species.

In this study, we isolated the $N^{\prime}$ gene and compared it with the Capsicum $L$ gene to identify those regions responsible for determining the spectrum of tobamovirus recognition. Our results showed that the Capsicum $\mathrm{L}$ and Nicotiana $\mathrm{N}^{\prime}$ proteins, although encoded by closely related $R$ genes, have diverged, leading to distinct recognition specificity. Functional differentiation was achieved by changes in the LRR domains represented by a conserved C-terminal sequence that contributed differentially to the recognition of the same Avr protein.

\section{RESULTS}

\section{Isolation of the $N^{\prime}$ gene.}

To isolate the $N^{\prime}$ gene, we used a homology-based approach because the $\mathrm{N}$ - and $\mathrm{C}$-terminal amino acid sequences of pepper $L$ gene alleles are completely conserved (Supplementary Fig. $\mathrm{S} 1$ ) and $N^{\prime}$ was predicted to be homologous to $L$ (Culver 2002). In addition, the $\mathrm{N}$ - and $\mathrm{C}$-termini of the $\mathrm{L}^{3}$ protein were shown to be important for its function (i.e., when fused with epitope tags at either the $\mathrm{N}$ or $\mathrm{C}$ terminus, the fusion proteins did not function in a transient assay system, although the proteins accumulated to detectable levels as shown by immunoblotting) (Supplementary Fig. S2). We performed polymerase chain reaction (PCR) to amplify $L$ gene homologs from the genomic DNA of Nicotiana spp. and obtained a PCR product of the $N^{\prime}$ candidate gene from $N$. sylvestris as a single band of approximately $4 \mathrm{~kb}$ (Fig. 1A). The nucleotide sequences of three independent clones revealed that the candidate gene of 4,140 nucleotides encoded a CC-NB-LRR-type R protein. Because the sequences of $5^{\prime}$ and $3^{\prime}$ ends in the initial $N^{\prime}$ candidate clone were those of primers used, we determined the true sequences of these regions by adaptor PCR. We found only a single nucleotide change in the $3^{\prime}$ end region between the $N^{\prime}$ candidate and $L^{3}$, and the clones with corrected sequence were hereafter used. The protein product of 1,380 amino acids shared a $68.7 \%$ amino acid sequence identity and $89.2 \%$ similarity with the $\mathrm{L}^{3}$ protein (Supplementary Figs. S3 and S4).

The $N^{\prime}$ candidate was introduced into the pBA binary vector (Tomita et al. 2011). A transient expression assay in $N$. benthamiana showed that the $N^{\prime}$ candidate could confer cell death in response to the coexpression of CP from ToMV, PaMMV, and $\mathrm{PMMoV}$, including pathotypes $\mathrm{P}_{1,2}, \mathrm{P}_{1,2,3}$, and $\mathrm{P}_{1,2,3,4}$, but not from TMV (Fig. 1B). The cell death was accompanied with accumulation of $\mathrm{H}_{2} \mathrm{O}_{2}$ and electrolyte leakage, suggesting that this response was an HR resulting from the recognition of tobamovirus $\mathrm{CP}$ by the $N^{\prime}$ candidate (Supplementary Figs. $\mathrm{S} 5 \mathrm{~A}$ and $\mathrm{B}$ and S6A). To test whether or not the $N^{\prime}$ candidate could confer resistance to tobamovirus infection, the $N^{\prime}$ candidate gene was coexpressed with a PMMoV vector (Tomita et al. 2011) expressing $C P$ from the PMMoV $P_{1,2}$ and $P_{1,2,3,4}$ pathotypes and TMV. The candidate gene conferred resistance

Table 1. Tobamovirus used in this study

\begin{tabular}{|c|c|c|c|c|c|c|c|c|c|}
\hline \multirow[b]{2}{*}{ Name } & \multirow[b]{2}{*}{ Pathotype } & \multirow[b]{2}{*}{ Virus species } & \multirow[b]{2}{*}{ Strain } & \multicolumn{5}{|c|}{ Pathogenicity to resistance gene ${ }^{\mathrm{a}}$} & \multirow[b]{2}{*}{ References } \\
\hline & & & & $N^{\prime}$ & $L^{1}$ & $L^{2}$ & $L^{3}$ & $L^{4}$ & \\
\hline ToMV & $\mathrm{P}_{0}$ & Tomato mosaic virus & $\mathrm{L}$ & avr & avr & avr & avr & avr & Meshi et al. 1986 \\
\hline TMV & $\mathrm{P}_{0}$ & Tobacco mosaic virus & K98 & vir & avr & avr & avr & avr & This study \\
\hline PaMMV & $\mathrm{P}_{1}$ & Paprika mild mottle virus & $\mathrm{J}$ & avr & vir & avr & avr & avr & Hamada et al. 2003 \\
\hline PIW & $\mathrm{P}_{1,2}$ & Pepper mild mottle virus & Iw & avr & vir & vir & avr & avr & Hamada et al. 2007 \\
\hline PIW-138N & $\mathrm{P}_{1,2,3}$ & Pepper mild mottle virus & I & avr & vir & vir & vir & avr & $\begin{array}{l}\text { Garcia-Luque et al. 1993; } \\
\text { Sakamoto et al. } 2008\end{array}$ \\
\hline PIW-46R85K & $\mathrm{P}_{1,2,3,4}$ & Pepper mild mottle virus & L4BV & avr & vir & vir & vir & vir & Genda et al. 2007 \\
\hline
\end{tabular}

a Abbreviations: avr = avirulent and vir $=$ virulent. 
to PMMoV $\mathrm{P}_{1,2}$ and $\mathrm{P}_{1,2,3,4}$ but not to TMV (Fig. 1C); therefore, the recognition specificity of the $N^{\prime}$ candidate was consistent with that of the $N^{\prime}$ gene in $N$. sylvestris (Table 1 ).

To confirm the expression of $\mathrm{L}$ and $\mathrm{N}^{\prime}$ proteins in the transient assay, we fused these proteins to epitope tags to detect their expression; however, the addition of tag sequences to the $5^{\prime}$ or $3^{\prime}$ terminus of the $L^{3}$ gene abolished its ability to induce the HR. Therefore, we sought a site to insert the tag sequence in $\mathrm{L}^{3}$ without affecting its function. We inserted the epitope tag sequence into regions that were predicted to form turn structures in a secondary structure prediction using the Chou-Fasman method. Eventually, the $\mathrm{L}^{3}$ protein was successfully tagged with the hemagglutinin (HA) tag without affecting its ability to confer the $\mathrm{HR}$ in response to $\mathrm{CP}$ coexpression, and the protein was detectable by immunoblotting (Fig. 1D). Likewise, $\mathrm{N}^{\prime}$ was tagged with $\mathrm{HA}$ at a similar turn structure in its $\mathrm{CC}$ domain. HA-tagged $\mathrm{N}^{\prime}$ elicited an HR upon coexpression of avirulent tobamoviruses and was detectable by immunoblotting using an anti-HA antibody (Fig. 1D). Unexpectedly, the $\mathrm{N}^{\prime}$ protein migrated faster than $\mathrm{L}^{3}$ in sodium dodecyl sulfate (SDS)-polyacrylamide gels, although the coding region of $N^{\prime}$ is longer than that of $L^{3}$. The analysis of cDNA ruled out the possibility of splicing in $N^{\prime}$ mRNA. The cause for inconsistent migration remains unknown but the difference in distribution of charged amino acids in these polypeptides might affect their electrophoretic mobility, as suggested for some virus CP (Gordon et al. 1988).

\section{Genetic analysis of $N^{\prime}$.}

$N$. tabacum is an amphidiploid generated from crossing $N$. sylvestris and $N$. tomentosiformis that is expected to carry the $N^{\prime}$ gene and show resistance to Tobamovirus spp. Although some N. tabacum cultivars such as 'Bright Yellow' and 'White Burley' are resistant to ToMV and other Tobamovirus spp., other cultivars such as N. tabacum 'Xanthi' and 'SR-1' are susceptible to all Tobamovirus spp. (Supplementary Fig. S7). In addition, N. tabacum 'Ky-57' (Ky) is resistant to all Tobamovirus spp. tested, suggesting that it has non- $N^{\prime}$ tobamovirus $R$ gene. To clarify the relevance of the $N^{\prime}$ gene to the tobamovirus resistance phenotype in $N$. tabacum, we tried to identify the $N$. tabacum $N^{\prime}\left(N t-N^{\prime}\right)$ genes and susceptible alleles $(N t-n)$.

PCR primers designed to amplify the $\mathrm{N}^{\prime}$ coding region amplified a single product from the genomic DNA of tobamovirus-resistant cultivars, including $N$. sylvestris. By contrast,

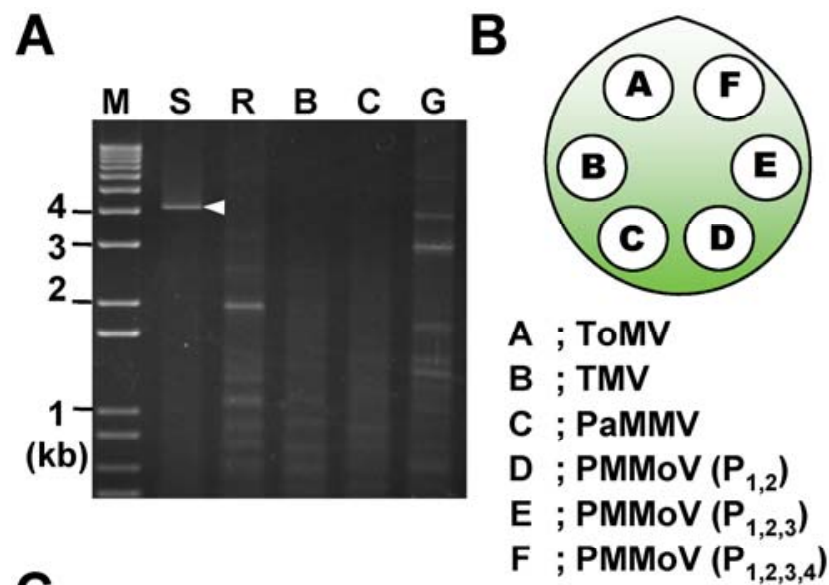

C

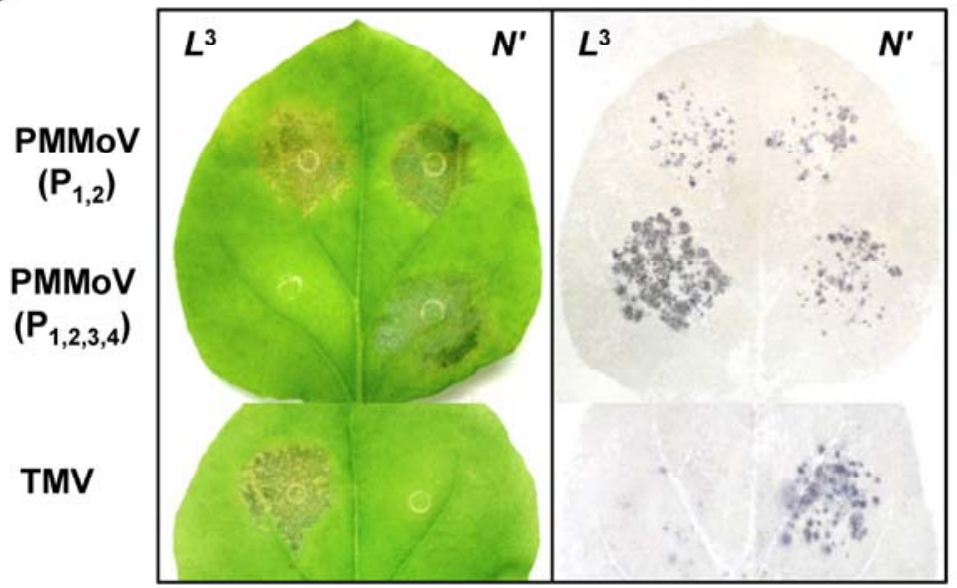

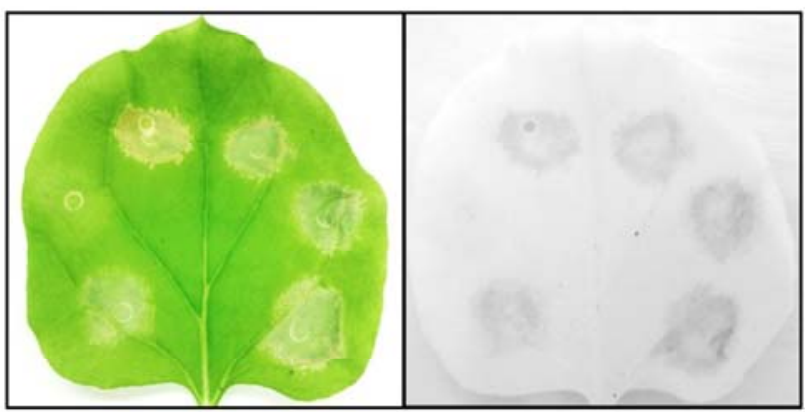

D

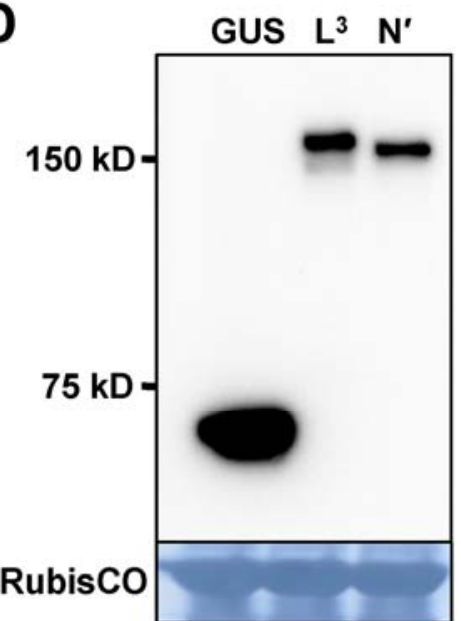

Fig. 1. Isolation of the $N^{\prime}$ gene. A, Electrophoresis of polymerase chain reaction (PCR) products amplified from the genomic DNA of Nicotiana plant species using the specific primers for the full-length coding region of the $L$ gene. PCR products amplified from Nicotiana sylvestris (S), N. rustica (R), N. benthamiana (B), N. clevelandii (C), and N. glutinosa (G) were analyzed with molecular weight markers (M). B, Hypersensitive response (HR) lesions in N. benthamiana leaves after coexpression of the candidate $N^{\prime}$ gene and tobamoviruses. Experimental settings are shown in the left diagram, in which six different tobamovirus coat proteins (A to F) were coexpressed with the $N^{\prime}$ candidate gene in $N$. benthamiana leaves. A $=$ Tomato mosaic virus (ToMV), $\mathrm{B}=$ Tobacco mosaic virus (TMV), $\mathrm{C}=$ Paprika mild mottle virus (PaMMV), and $\mathrm{D}$ to $\mathrm{F}=$ Pepper mild mottle virus (PMMoV) pathotypes. Four days after agroinfiltration, the leaves were photographed (left panel), cleared with ethanol, and photographed again (right panel). Accumulation of each protein was confirmed by immunoblotting. C, Resistance to tobamoviruses in $N$. benthamiana leaves conferred by transient expression of the candidate $N^{\prime}$ gene. HR lesions on the leaves were photographed (left panel). Viral spread was detected by tissue printing immunoblotting (right panel). In each leaf, $L^{3}$ (on the left side) and the $N^{\prime}$ candidate (on the right side) were coexpressed with $\operatorname{PMMoV}\left(\mathrm{P}_{1,2}\right), \operatorname{PMMoV}\left(\mathrm{P}_{1,2,3,4}\right)$, or TMV. D, Immunoblot of proteins extracted from $N$. benthamiana leaves transiently expressing $\beta$-glucuronidase (GUS)-hemagglutinin (HA) (GUS), $\mathrm{L}^{3}-\mathrm{T} 3-\mathrm{HA}\left(\mathrm{L}^{3}\right)$, or $\mathrm{N}^{\prime}$-T3-HA $\left(\mathrm{N}^{\prime}\right)$. Proteins were detected using an anti-HA antibody. In the bottom box, the RubisCO large subunit protein stained with Amido Black is shown as a loading control. 
the same primers amplified two bands from the susceptible cultivars and Ky: one band was identical in size to that amplified from resistant plants and the other was about $1 \mathrm{~kb}$ longer (Fig. 2A). These results led us to hypothesize that there were two $N t-n^{\prime}$ alleles, one with an insertion and another with a point mutation. To test this hypothesis, we performed PCR using another set of primers designed to amplify the region including the $5^{\prime}$-untranslated region (UTR) and $3^{\prime}$-UTR of $N^{\prime}$. We observed that $N t-n^{\prime}$ was amplified, unexpectedly, as a single band that was larger than $N^{\prime}$ and $N t-N^{\prime}$ (Fig. 2B). Sequence analysis revealed that the larger PCR fragment from susceptible cultivars consisted of a complete $N^{\prime}$ coding sequence and a duplicated 902 -bp sequence $\left(90 \mathrm{bp}\right.$ of the $5^{\prime}$-UTR region and 812 bp of the $\mathrm{N}^{\prime}$ protein coding sequence) (Fig. 2C; Supplementary Fig. S8). The forward primer for amplifying the $N^{\prime}$ coding region was annealed to the two positions in $N t-n^{\prime}$ (in both copies of duplicated regions) (Fig. 2C, arrows labeled with "a"), resulting in the amplification of two DNA fragments of different sizes. The upstream copy of the duplicated sequences had a stop codon upstream of the complete $\mathrm{N}^{\prime}$ coding sequence, a feature likely to compromise the translation of the downstream $N^{\prime}$ gene and to result in plant susceptibility to tobamovirus. The resistance to TMV in Ky, which suggests that Ky has another type of tobamovirus $R$ gene, is consistent with our findings that it had $N t-n^{\prime}$ rather than $N t-N^{\prime}$ (Fig. 2B). These results support the hypothesis that the candidate gene cloned from $N$. sylvestris using the homology-based method is the $N^{\prime}$ gene.

We examined the phylogenetic relationship between the $N^{\prime}$ and $L$ alleles. Analysis of the NB domain-encoding regions from $N^{\prime}, L$ alleles, and previously analyzed related sequences (Couch et al. 2006) revealed that the NB-encoding region of $\mathrm{N}^{\prime}$ was more closely related to $I 2$ (Simons et al. 1998), $R 3 a$ (Huang et al. 2005), and $P I H-X$, a paralog of $L^{3}$ with unknown function (Tomita et al. 2011), than to the $L$ alleles (Supplementary Fig. S9A). Interestingly, analysis of regions encoding the C-terminal half of the LRR domain (LRR2 regions) gave contrasting results. The LRR2 region of $\mathrm{N}^{\prime}$ was much more closely related to those of the $L$ alleles than to those of $I 2$ and $R 3 a$; however, PIH-X was more closely related to the $L$ alleles than to $N^{\prime}$.

A

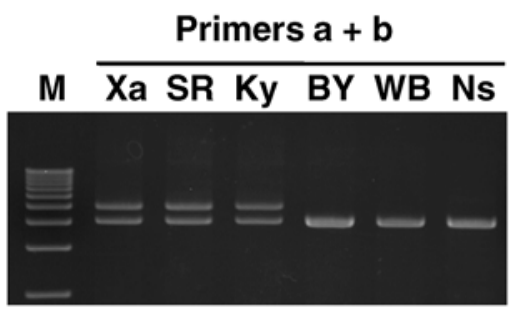

\section{Identification of domains determining}

the tobamovirus-recognition specificity of $N^{\prime}$ and $L^{3}$ proteins.

We previously showed that the C-terminal halves of the LRR domains from allelic L proteins are critical for determining the spectra of $\mathrm{R}$ proteins recognizing Avr tobamovirus $\mathrm{CP}$. Therefore, we performed a domain swap analysis between $\mathrm{N}^{\prime}$ and $\mathrm{L}^{3}$ to identify those regions contributing to recognition specificity (i.e., TMV recognition by $\mathrm{L}^{3}$ and $\mathrm{P}_{1,2,3,4}$ recognition by $\mathrm{N}^{\prime}$ ).

First, to confirm whether the LRR domains of the $\mathrm{L}^{3}$ and $\mathrm{N}^{\prime}$ proteins determine their own recognition specificity, we constructed chimeras in which $\mathrm{L}^{3}$ and $\mathrm{N}^{\prime}$ were recombined around the junction between the NB and LRR domains. These chimeras, termed L5N and N5L, respectively, were coexpressed with CP from ToMV, TMV, or PMMoV $\left(\mathrm{P}_{1,2,3,4}\right)$, which were expressed using a PMMoV vector, pBTPIW (Fig. 3A and B). L5N conferred the HR in the same pattern as $\mathrm{N}^{\prime}$, suggesting that the LRR domain determines recognition specificity; however, N5L conferred the HR to PMMoV $\left(\mathrm{P}_{1,2,3,4}\right)$, unlike $\mathrm{L}^{3}$. Rairdan and Moffett (2006) showed that the combination of GPA2-ARC2 and $\mathrm{Rx}-\mathrm{LRR}$ in a chimera of these $\mathrm{R}$ proteins caused CPindependent HR (autoactivation phenotype). To test whether the N5L protein also can exhibit a CP-independent HR, N5L, $\mathrm{L} 5 \mathrm{~N}, \mathrm{~L}^{3}$, and $\mathrm{N}^{\prime}$ proteins were coexpressed with a genesilencing suppressor ( 19 from Tomato bushy stunt virus). The overexpression of N5L induced HR lesions independently of tobamovirus $\mathrm{CP}$, indicating that $\mathrm{N} 5 \mathrm{~L}$ shows the autoactivation phenotype (Fig. 3B) noted that even the coexpression of N5L with GFP, which served as a negative control for other R protein constructs, induced cell death as manifested by electrolyte leakage. Although it remains unclear whether the LRR domain of $\mathrm{L}^{3}$ could recognize $\mathrm{P}_{1,2,3,4} \mathrm{CP}$ when combined with the $\mathrm{CC}$ domain from $\mathrm{N}^{\prime}$, recognition of $\mathrm{P}_{1,2,3,4} \mathrm{CP}$ is conditioned by the LRR domain from $\mathrm{N}^{\prime}$.

To define more narrowly the region determining recognition specificity, some additional chimeras were constructed by recombining $\mathrm{N}^{\prime}$ and $\mathrm{L}^{3}$ within the stretches of conserved sequence, and these chimeras were tested for their ability to recognize tobamovirus $\mathrm{CP}$ (Fig. 3A and C). L7N and N7L perceived viruses with the same specificity as $\mathrm{N}^{\prime}$ and $\mathrm{L}^{3}$, respec-

B Primers c + d M Xa SR Ky BY WB Ns

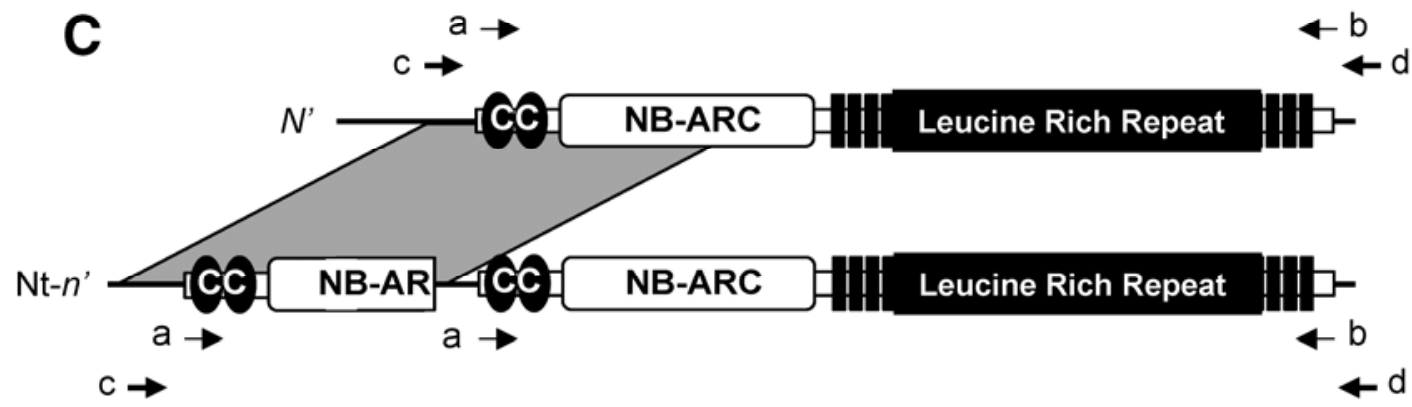

Fig. 2. $N^{\prime}$ alleles in Nicotiana tabacum cultivars. A and B, Electrophoresis of polymerase chain reaction (PCR) products amplified from the genomic DNA of N. tabacum cultivars using the specific primer sets shown in C. PCR products amplified from N. tabacum 'Xanthi' (Xa), 'SR-1' (SR), 'Ky-57' (Ky), 'Bright Yellow' (BY), and 'White Burley' (WB), and from $N$. sylvestris (Ns) were analyzed with molecular weight markers (M). C, A diagram for the gene structures of $N^{\prime}$ and the tobamovirus-susceptible allele $N t-n^{\prime}$. Arrows show the annealing sites and directions of the primers (a-d). A gray area indicates a duplicated part of $N^{\prime}$. NB = nucleotide-binding site, $\mathrm{CC}=$ coiled coil, and $\mathrm{ARC}=\mathrm{ApafI}, \mathrm{R}$ proteins, and CED4 region. 
tively. L9N conditioned the HR to those viruses recognized by $\mathrm{N}^{\prime}$. These results suggest that the C-terminal half of the LRR of the $\mathrm{N}^{\prime}$ protein determines its specificity to recognize tobamoviruses. In contrast, N9L, L11N, and N11L were not functional, although they accumulated to comparable levels as $\mathrm{L}^{3}$ and $\mathrm{N}^{\prime}$ when they triggered the $\mathrm{HR}$ in response to matching $\mathrm{CP}$ (Supplementary Fig. S10B). These results suggest that $\mathrm{L}^{3}$ and $\mathrm{N}^{\prime}$ have differentiated to show distinct LRR configuration and, therefore, some subdomains are not interchangeable.

\section{Functional differentiation}

of the $\mathrm{C}$-terminal regions of $\mathrm{N}^{\prime}$ and $\mathrm{L}^{3}$.

The $5^{\prime}$ - and $3^{\prime}$-terminal regions of the $N^{\prime}$ and $L$ genes are highly conserved and have important roles in resistance because fusion of unrelated sequences in these regions, such as HA or c-Myc tags, abolished their function. Additionally, the C-terminal halves of the LRR domains from $\mathrm{N}^{\prime}$ and $\mathrm{L}$ determined their recognition specificity (Fig. 4). These results suggested that the $\mathrm{C}$-terminal conserved sequence has a significant role in the recognition of common viral proteins by $\mathrm{L}$ and $\mathrm{N}^{\prime}$. To explore the role of the conserved $\mathrm{C}$-terminal regions, we constructed a series of deletion mutants in the $\mathrm{C}$-terminal regions of $\mathrm{L}^{3}$ and $\mathrm{N}^{\prime}$. In $\mathrm{N}^{\prime}$, deletion of three amino acids totally abolished its ability to recognize all tobamovirus CP. By contrast, in $\mathrm{L}^{3}$, mutants lacking 5 or 10 amino acids were still able to recognize CP from ToMV, TMV, and PaMMV or that of ToMV alone. An $\mathrm{L}^{3}$ mutant lacking the C-terminal 15 amino acids was unable to recognize tobamovirus CP (Fig. 4A and B). Decreasing recognition by the $\mathrm{L}^{3}$ mutants was not the result of decreased protein accumulation because we found no correlation between the recognition spectrum and protein accumulation levels of the deletion mutant proteins. These results collectively indicate that the significance of the $\mathrm{C}$-terminal regions has differentiated between $\mathrm{L}^{3}$ and $\mathrm{N}^{\prime}$ (i.e., the $\mathrm{C}$-terminal region of $\mathrm{N}^{\prime}$ has a pivotal role in its basic function, whereas that of $\mathrm{L}^{3}$ has additive effects).

Because the deletion of 10 amino acids (GRTMFDCECL) but not 5 amino acids (DCECL) compromised TMV recogni-

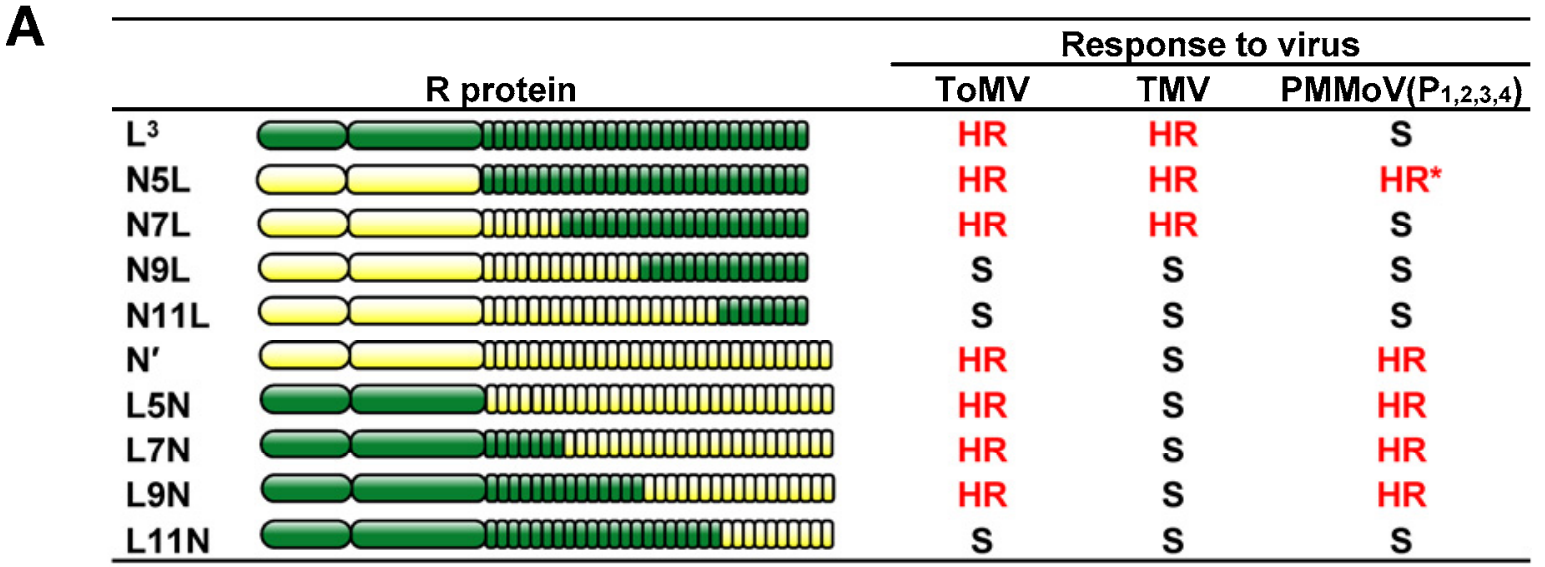

B
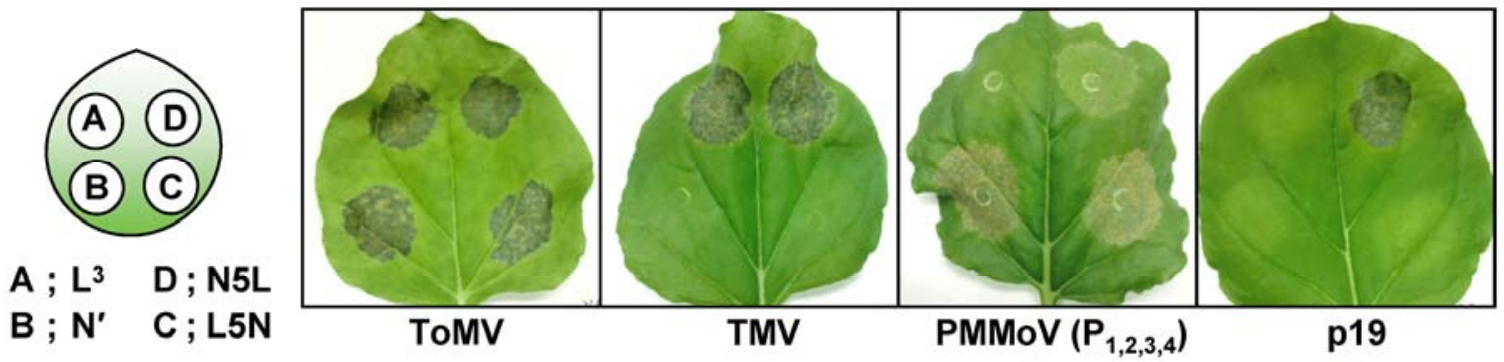

ToMV

TMV

PMMoV $\left(P_{1,2,3,4}\right)$

p19
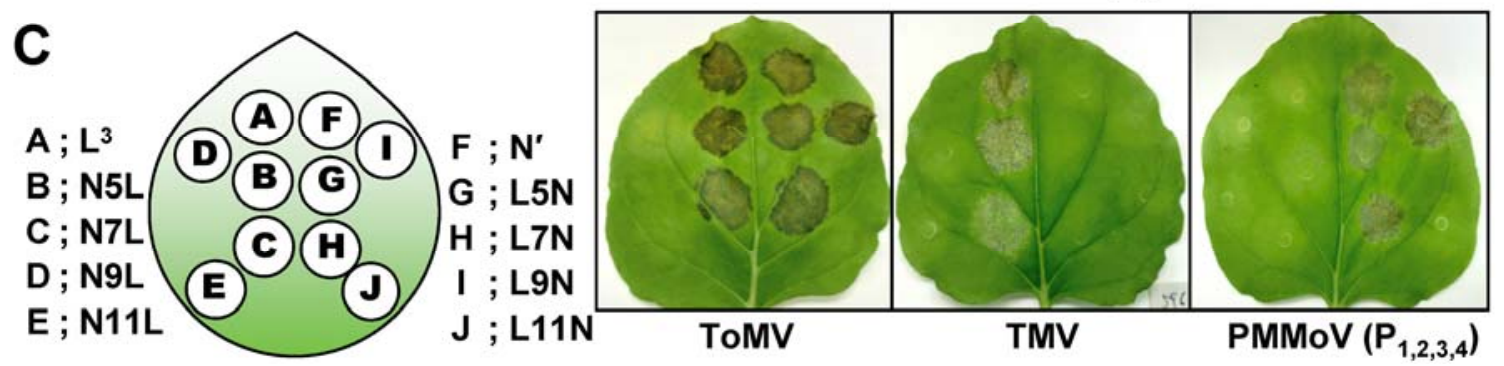

Fig. 3. Chimeric analysis between the $N^{\prime}$ and $L^{3}$ genes. A, Summary of the chimeric analysis between the $N^{\prime}$ and $L^{3}$ genes. The names of the resistance (R) protein constructs, schemes of chimeric proteins, and phenotypes in the transient expression assay with each of four different tobamovirus coat proteins (CP are shown. HR, hypersensitive response (HR) induction after coexpression of R proteins and tobamovirus CP; S, lack of visible HR lesion development; HR*, HR induction by the autoactivation of chimeric R protein (see text). B, Response of the chimeric R proteins L5N and N5L to different tobamovirus. Experimental settings are shown in the left diagram, in which four different R proteins ( $\mathrm{L}^{3}, \mathrm{~N}^{\prime}$, L5N, or N5L) were coexpressed with Tomato mosaic virus (ToMV), Tobacco mosaic virus (TMV), Pepper mild mottle virus (PMMoV) pathotype $\left(\mathrm{P}_{1,2,3,4}\right)$, or the gene-silencing suppressor $\mathrm{p} 19$ in Nicotiana benthamiana leaves. Five days after agroinfiltration, the leaves were photographed. $\mathbf{C}$, Response of various chimeric $\mathrm{R}$ proteins to different tobamovirus. Experimental settings are shown in the left diagram, in which 10 different R proteins $\left(\mathrm{L}^{3}, \mathrm{~N}^{\prime}, \mathrm{L} 5 \mathrm{~N}, \mathrm{~N} 5 \mathrm{~L}, \mathrm{~L} 7 \mathrm{~N}, \mathrm{~N} 7 \mathrm{~L}, \mathrm{~L} 9 \mathrm{~N}, \mathrm{~N} 9 \mathrm{~L}, \mathrm{~L} 11 \mathrm{~N}\right.$, or N11L) were coexpressed with ToMV, TMV, or PMMoV $\left(\mathrm{P}_{1,2,3,4}\right)$ in $N$. benthamiana leaves. Five days after agroinfiltration, the leaves were photographed. Accumulation of each protein was confirmed by immunoblotting. 
A

\begin{tabular}{|c|c|c|c|c|c|}
\hline \multirow[b]{2}{*}{$\mathbf{R}$ protein } & \multirow[b]{2}{*}{ Amino acid sequence in C-terminus } & \multicolumn{4}{|c|}{ Response to virus } \\
\hline & & ToMV & TMV & PaMMV & PMMoV \\
\hline & $\begin{array}{lll}1315 & 1320 & 1325 \\
\end{array}$ & & & & \\
\hline $\mathbf{L}^{3}$ & - HIPEIYIGRTMFDCECL * & HR & HR & HR & HR \\
\hline $\mathrm{L}^{3} \mathrm{dC} 15$ & $-\mathbf{H ~ I} *$ & $\mathbf{s}$ & $\mathbf{s}$ & $\mathbf{s}$ & $\mathbf{s}$ \\
\hline $\mathrm{L}^{3} \mathrm{dC} 10$ & - H I PE I Y I* & HR & $\mathbf{S}$ & $\mathbf{S}$ & $\mathbf{S}$ \\
\hline $\mathrm{L}^{3} \mathrm{dC} 5$ & - H I PE I Y I GRTMF* & HR & HR & HR & $\mathbf{s}$ \\
\hline L $^{3} \mathrm{dGRTMF}$ & - H I PE I Y I ............ DCE C L & HR & HR & HR & $\mathbf{s}$ \\
\hline Lª'dPEIYI & - H I .............. GRTMF DCE C L * & HR & HR & $\mathbf{s}$ & $\mathbf{s}$ \\
\hline$L^{3} \mathrm{D} 1324 \mathrm{~A}$ & - H I PE I Y I GRTMFACECL * & HR & HR & HR & HR \\
\hline L'ㄴR32AIAIA & -HIPA IA IARTMFDCECL * & HR & $\mathrm{HR}$ & HR. & $\mathbf{S}$ \\
\hline & $\begin{array}{lll}1370 & 1375 & 1380\end{array}$ & & & & \\
\hline $\mathbf{N}^{\prime}$ & - H I P N I V I .............. DCECL * & HR & $\mathbf{S}$ & HR & HR \\
\hline N'dC10 & $-\mathbf{H ~ I} *$ & $\mathbf{s}$ & s & $\mathbf{s}$ & $\mathbf{s}$ \\
\hline N'dC5 & - H I P N I V I* & $\mathbf{S}$ & s & $\mathbf{S}$ & S \\
\hline N'dC3 & - H I P N I V I ................ D C * & $\mathbf{s}$ & $\mathbf{s}$ & s & $\mathbf{s}$ \\
\hline N'iGRTMF & - H I PN IVIGRTMFDCECL* & $\mathbf{S}$ & $\mathbf{S}$ & $\mathbf{s}$ & $\mathbf{S}$ \\
\hline
\end{tabular}

B

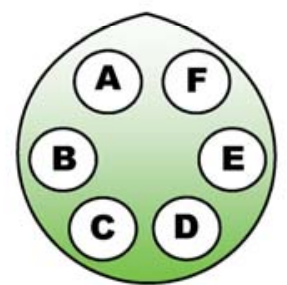
A ; GUS
F ; ${ }^{3} \mathrm{dC} 15$
$B ; L^{3}$
C ; $\mathrm{L}^{3} \mathrm{dC} 5$
E ; $\mathrm{L}^{3} \mathrm{dC} 10$
D ; L'3dGRTMF

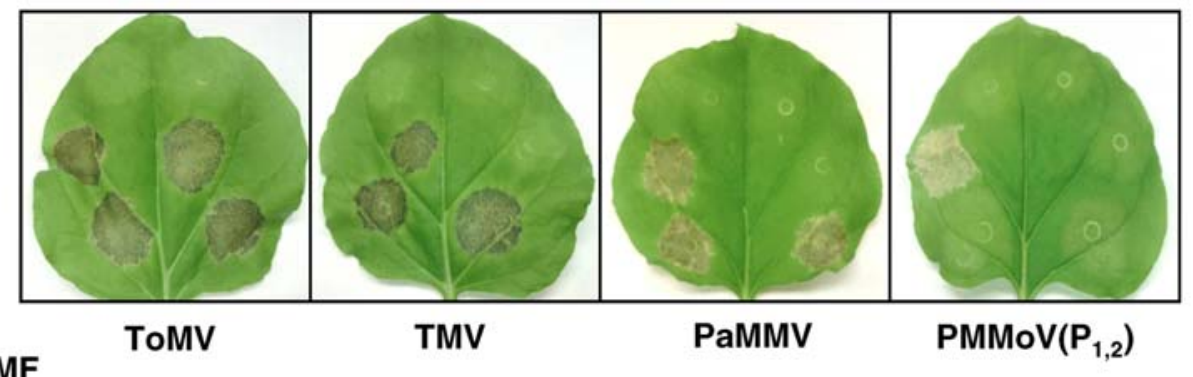

\section{C}

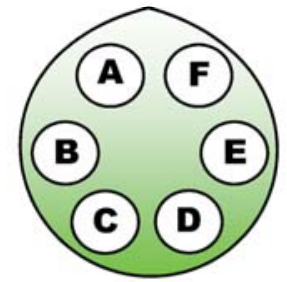
$A ; L^{3}$
$F$; N'dC10
$B$; N'IGRTMF
$E$; N'dC5
$C ; N^{\prime}$
D; N'dC3

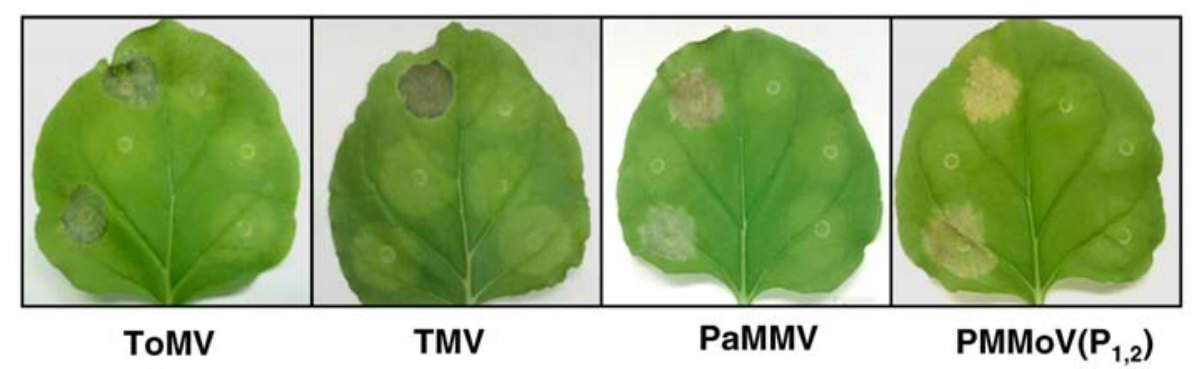

D
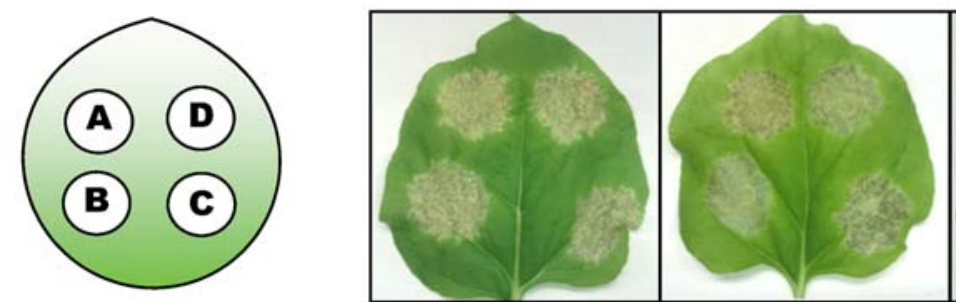
$A ; L^{3}$
D ; L'LRR32AIAIA
ToMV
B ; L ${ }^{3} \mathrm{dPEIYI} \mathrm{C} \mathrm{;} \mathrm{{ } ^ { 3 } \mathrm { D } 1 3 2 4 A}$

TMV

Fig. 4. Deletion, insertion, and substitution mutant analysis of the C-terminal regions in $\mathrm{N}^{\prime}$ and $\mathrm{L}^{3}$. A, Summary of the deletion, insertion, and substitution mutagenesis analysis of the $\mathrm{C}$-terminal region in $\mathrm{N}^{\prime}$ and $\mathrm{L}^{3}$. In the table, the names of the mutant resistance (R) proteins, $\mathrm{C}$-terminal amino acid sequences, and their phenotypes under coexpression with each of the four different coat proteins from Tomato mosaic virus (ToMV), Tobacco mosaic virus (TMV), Paprika mild mottle virus (PaMMV), and Pepper mild mottle virus (PMMoV) are shown. HR, hypersensitive response (HR) induction after the coexpression of the combination of wild-type or mutant R proteins; S, susceptible, defined by the lack of visible HR lesion development. B, Responses of the C-terminal mutants of $\mathrm{L}^{3}$. Experimental settings are shown in the left diagram, in which $\beta$-glucuronidase (GUS), wild-type $\mathrm{L}^{3}\left(\mathrm{~L}^{3}\right), \mathrm{L}^{3} \mathrm{dC}$, $\mathrm{L}^{3} \mathrm{dGRTMF}, \mathrm{L}^{3} \mathrm{dC} 10$, or $\mathrm{L}^{3} \mathrm{dC} 15$ were coexpressed with ToMV, TMV, PaMMV, or PMMoV $\left(\mathrm{P}_{1,2}\right)$ in Nicotiana benthamiana leaves. C, Responses of the C-terminal mutants of $\mathrm{N}^{\prime}$. Experimental settings are shown in the left diagram, in which $\mathrm{L}^{3}, \mathrm{~N}^{\prime} \mathrm{iGRTMF}$, wild-type $\mathrm{N}^{\prime}\left(\mathrm{N}^{\prime}\right), \mathrm{N}^{\prime} \mathrm{dC} 3, \mathrm{~N}^{\prime} \mathrm{dC}$, or $\mathrm{N}^{\prime} \mathrm{dC} 10$ were coexpressed with ToMV, TMV, PaMMV, or PMMoV $\left(\mathrm{P}_{1,2}\right)$ in N. benthamiana leaves. D, Responses of the C-terminal mutants of $\mathrm{N}^{\prime}$. Experimental settings are shown in the left diagram, in which $\mathrm{L}^{3}, \mathrm{~L}^{3} \mathrm{dPEIYI}, \mathrm{L}^{3} \mathrm{D} 1324 \mathrm{~A}$, or $\mathrm{L}^{3} \mathrm{LRR} 32 \mathrm{AIAIA}$ were coexpressed with ToMV, TMV, PaMMV, or PMMoV $\left(\mathrm{P}_{1,2}\right)$ in $N$. benthamiana leaves. All of the leaves were photographed at 5 days postagroinfiltration. Accumulation of each protein was confirmed by immunoblotting. 
tion, we hypothesized that $\mathrm{N}^{\prime}$ cannot recognize TMV because it lacks the GRTMF sequence (Fig. 4A and B). To test this hypothesis, we assessed the recognition specificity of GRTMFinserted $\mathrm{N}^{\prime}$ (N'iGRTMF) (Fig. 4A and C) and GRTMF-deleted $\mathrm{L}^{3}$ ( $\mathrm{L}^{3} \mathrm{dGRTMF}$ ) (Fig. 4A and B). Unexpectedly, GRTMFinserted $\mathrm{N}^{\prime}$ still showed no function, whereas the GRTMFdeleted $\mathrm{L}^{3}$ mutant recognized TMV CP, although the latter did not recognize $\mathrm{PMMoV} \mathrm{CP}$. This result indicates that the GRTMF sequence, although it is present in the $\mathrm{L}^{3}$ that recognizes TMV CP and absent in the $\mathrm{N}^{\prime}$ that does not recognize TMV CP, does not have a crucial role in TMV CP recognition. In addition, the result suggests that the length of the C-terminal region is more important than the context of the amino acid sequence for determining recognition specificity in $\mathrm{L}^{3}$. To examine this possibility, we tested whether the deletion of five different amino acids (PEIYI from the upstream region) affected only the recognition of PMMoV CP ( $\mathrm{L}^{3} \mathrm{dPEIYI)}$ (Fig. $4 \mathrm{~A}$ and $\mathrm{D})$. The PEIYI-deletion mutant was compromised in the recognition of not only PMMoV CP but also PaMMV CP, suggesting that both the length of and the sequence context in the C-terminal region play important roles in the determination of recognition specificity.
Importance of the C-terminal-most copy of the $x x \operatorname{LxLxx} \beta$-sheet motif in recognition.

Next, we analyzed the significance of the C-terminal DCECL sequence that was perfectly conserved between the $L$ alleles and $N^{\prime} . N^{\prime}$ was mutated by alanine scanning, in which the $1376 \mathrm{D}, 1377 \mathrm{C}, 1378 \mathrm{E}, 1379 \mathrm{C}$, or $1380 \mathrm{~L}$ of $\mathrm{N}^{\prime}$ was substituted with $A$ to generate N'D1376A, N'C1377A, N'E1378A, N'C1379A, or N'L1380A, respectively. N'C1377A and $\mathrm{N}^{\prime} \mathrm{C} 1379 \mathrm{~A}$ showed normal function that was indistinguishable from that of wild-type $\mathrm{N}^{\prime}$ (Fig. 5B). In contrast, $\mathrm{N}^{\prime} \mathrm{D} 1376 \mathrm{~A}$ lost the ability to recognize all of the assayed viral CP (Fig. 5B). N'E1378A and N'L1380A induced a delayed HR, characterized by a statistically significant decrease in ion leakage (Fig. 5C).

In contrast to $\mathrm{N}^{\prime} \mathrm{D} 1376 \mathrm{~A}$ protein, substitution of $1324 \mathrm{D}$ to $\mathrm{A}$ in $\mathrm{L}^{3}$ protein $\left(\mathrm{L}^{3} \mathrm{D} 1324 \mathrm{~A}\right)$ (Fig. 4A and $\mathrm{D}$ ) did not affect its recognition specificity. It should be noted that, in the $\mathrm{N}^{\prime}$ protein, the $1376 \mathrm{D}$ corresponds to $\mathrm{x}$, a putative solvent-exposed residue, in the xxLxLxx $\beta$-sheet motif, but the 1324D of the $\mathrm{L}$ proteins does not. The PEIYI-deletion mutant of $\mathrm{L}^{3}$ ( $\left.\mathrm{L}^{3} \mathrm{dPEIYI}\right)$ (Fig. 4A and D) that failed to recognize PaMMV and PMMoV $\mathrm{CP}$ had lost a copy of this motif. The results suggest that muta-

\begin{tabular}{llccc}
\hline & C-terminal & \multicolumn{3}{c}{ Response to virus } \\
\cline { 3 - 5 } R protein & sequence & ToMV & PaMMV & PMMoV \\
\hline N' & - D C ECL & HR & HR & HR \\
N'D1376A & - A CECL & S & S & S \\
N'C1377A & - D A E C L & HR & HR & HR \\
N'E1378A & - D C ACL & DHR & DHR & DHR \\
N'C1379A & - D C E A L & HR & HR & HR \\
N'L1380A & - DCECA & DHR & DHR & DHR \\
\hline
\end{tabular}

B

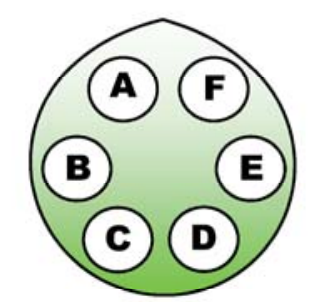

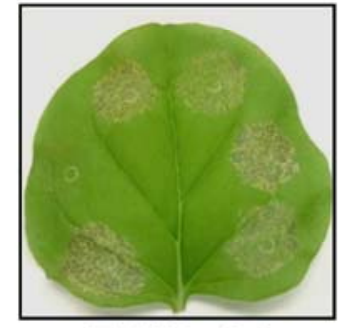

ToMV 5dpi

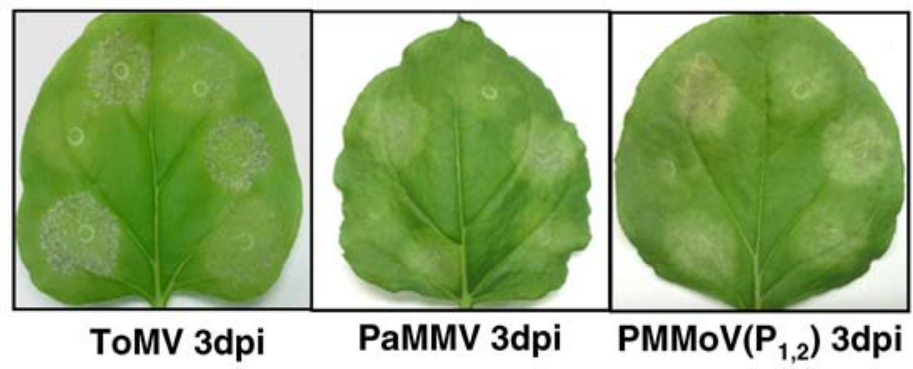

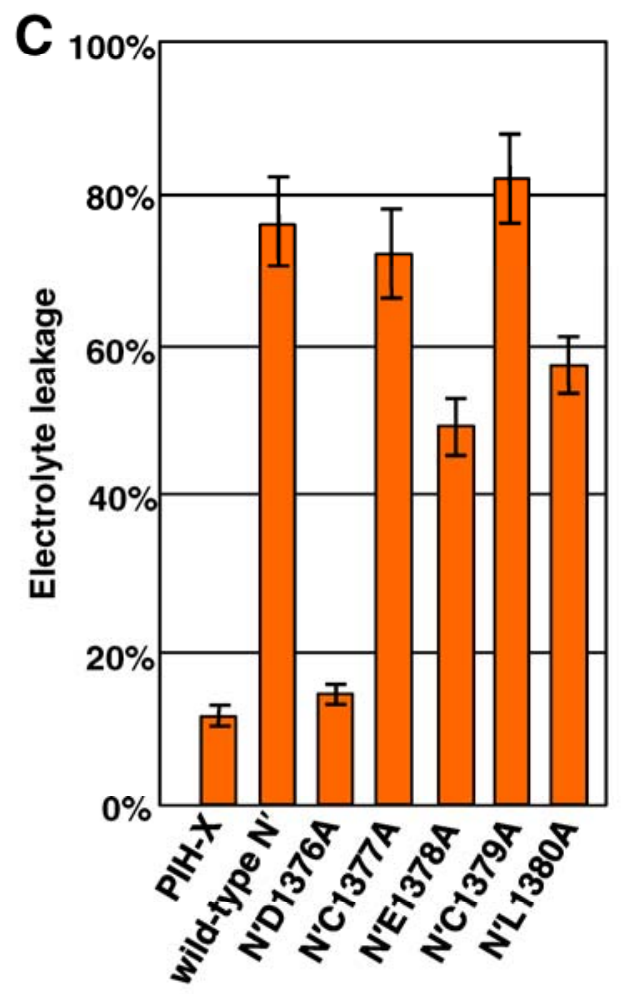

Fig. 5. Alanine scanning analysis in the C-terminal region of $\mathrm{N}^{\prime}$. A, Summary of alanine scanning analysis in the C-terminal region of $\mathrm{N}^{\prime}$. The names of the C-terminal single amino acid substitution mutant $\mathrm{N}^{\prime}$ proteins, C-terminal amino acid sequences, and phenotypes induced by their coexpression with the coat proteins (CP) of Tomato mosaic virus (ToMV), Paprika mild mottle virus (PaMMV), or Pepper mild mottle virus $(\mathrm{PMMoV})$ ( $\left.\mathrm{P}_{1,2}\right)$ are shown. HR, hypersensitive response (HR) induction after the coexpression of resistance (R) protein and CP; DHR, HR induction that was slower than that by combination of wildtype $\mathrm{N}^{\prime}$ and $\mathrm{CP}$; S, no induction of visible HR lesions. B, Responses of the C-terminal single amino acid substitution mutants to tobamovirus CP. Experimental settings are shown in the left scheme, in which PIH-X, wild-type N', N'D1376A, N'C1377A, N'E1378A, N'C1379A, or N'L1380A were coexpressed with ToMV, PaMMV, or PMMoV $\left(\mathrm{P}_{1,2}\right)$ in Nicotiana benthamiana leaves. At 3 or 5 days postagroinfiltration (dpi), the leaves were photographed. $\mathbf{C}$, Electrolyte leakage was measured in $N$. benthamiana leaves at 4 dpi to express an $\mathrm{R}$ protein with Tomato mosaic virus. Ratios of leaked electrolyte to total electrolyte were calculated, and error bars indicate the standard error. Detectable accumulation of each protein was confirmed by immunoblotting. 
tions of solvent-exposed residues in the C-terminal-most copy of the $\beta$-sheet motif affect the recognition function (i.e., they totally abolish the function of $\mathrm{N}^{\prime}$ and reduce the recognition spectrum of $\mathrm{L}^{3}$ ). To test this possibility, the $\mathrm{C}$-terminal-most copy of the $\beta$-sheet motif in the LRR of $\mathrm{L}^{3}$ (PEIYIGR) was altered to PAIAIAR, designated as L $^{3}$ LRR32AIAIA (Fig. 4A and D). L $^{3}$ LRR32AIAIA did not induce the HR when coexpressed with PMMoV CP, suggesting that the C-terminal-most copy of the $\beta$-sheet motif is important for recognition.

Amino acid substitution in N'D1376A totally abolished the recognition of tobamovirus CP. In contrast, $\mathrm{L}^{3}$ LRR32AIAIA did not recognize PMMoV CP but did recognize ToMV, TMV, and PaMMV, although these two mutants share the feature that one or a few solvent-exposed residues in the C-terminal-most copy of the xxLxLxx $\beta$-sheet motif were changed to alanine. These results again indicate that the $\mathrm{C}$-terminal region of $\mathrm{N}^{\prime}$ is important for the overall function of the protein but that of $\mathrm{L}^{3}$ is additive.

\section{DISCUSSION}

\section{Homology-based cloning of $\mathrm{N}^{\prime}$.}

Phylogenetic analysis suggested that the tobacco $N^{\prime}$ and pepper $L$ genes evolved from a common ancestor. The $I 2$ family genes, to which $L$ and $N^{\prime}$ belong, were reported to be monophyletic, to have diversified within the Solanaceae over 14 million years, and to have evolved through a slow birth-and-death process (Couch et al. 2006). In contrast to other types of genes, such as those encoding specific enzymes, it is not easy to use PCR to amplify and clone functional copies of an $R$ gene based on its homology to a previously characterized $R$ gene because plant genomes contain many $R$ gene copies and their sequences have diverged through evolution (Gao et al. 2007). The exceptions to this generally are the allelic $R$ genes, that branched in a comparatively recent time (Lanfermeijer et al. 2005; Tomita et al. 2011). The $\mathrm{N}$ - and C-termini of $\mathrm{N}^{\prime}$ and $\mathrm{L}$ are likely conserved due to functional constraints. Thus, we were able to amplify the $N^{\prime}$ gene by PCR using primers designed from the $L^{3}$ sequence (Fig. 1), although these $R$ genes are not allelic, and from different taxa.

Remarkably, Pseudomonas $R$ genes, Arabidopsis RPM1, and soybean Rpg1-b share pathogen-recognition specificity but exhibit low amino acid sequence similarity (Ashfield et al. 2004). In contrast, allelic $R$ genes can recognize distinct pathogens; for example, Arabidopsis RPP8, HRT, and $R C Y 1$ are alleles and their protein products share approximately 95\% amino acid sequence similarity; however, they confer resistance to Hyaloperonospora parasitica, Turnip crinkle virus, and Cucumber mosaic virus, respectively (Cooley et al. 2000; McDowell et al. 1998; Takahashi et al. 2002). Although these facts explain the difficulty in using PCR to obtain specific $R$ genes, the use of a cloning strategy based on conserved sequences has recently become a more feasible approach to identify $R$ gene homologs with the same recognition specificity from phylogenetically related plants. A recent approach called allele mining enabled the isolation of novel $R$ gene alleles with desired function from different species by largescale comparative analysis of structurally related genes (Bhullar et al. 2009, 2010; Wang et al. 2008). More recently, Jordan and associates (2011) identified TmMlal through intergeneric allele mining, in which a diploid wheat bacterial artificial chromosome library was screened using a probe to the $\mathrm{N}$-terminal region of the barley HvMlal LRR. Together with the study by Jordan and associates (2011), our results are encouraging that new functional homologs of a given $R$ gene can be identified from a different genus or a more distant taxon.

\section{Differentiation of $\mathrm{N}^{\prime}$ and $\mathrm{L}$ in their mode of tobamovirus $\mathrm{CP}$ recognition.}

Chimera analysis revealed that the recognition specificity of $\mathrm{N}^{\prime}$ and $\mathrm{L}^{3}$ is determined by their LRR domains (Fig. 3). The LRR domains of these two proteins were interchangeable (Fig. 3, L7N and N7L), although the first 200 amino acids of the LRR domains regulate the switching between active and inactive states, as suggested by the autoactivation of the N5L chimera (Fig. 3B). Nonetheless, a series of observations suggested that the LRR domains of $\mathrm{N}^{\prime}$ and $\mathrm{L}^{3}$ have functionally differentiated.

First, the N5L chimera showed autoactivation activity accompanied with the induction of the $\mathrm{HR}$ without recognition of $\mathrm{CP}$ (Fig. 3B). This phenomenon might be caused by an inappropriate intramolecular interaction between the NB and LRR domains (Rairdan and Moffett 2006).

Second, three chimeras (N9L, N11L, and L11N) were not functional, indicating that some of the LRR subregions are not interchangeable between $\mathrm{N}^{\prime}$ and $\mathrm{L}^{3}$. In the case of the chimeras for the L alleles, the LRR subregions were interchangeable and, thus, we could narrow down the regions required for broad-spectrum recognition (Tomita et al. 2011). The LRR domains of $\mathrm{N}^{\prime}$ and $\mathrm{L}^{3}$ share $81.5 \%$ similarity, whereas the L proteins share 98.7 to $100.0 \%$ similarity. In addition, the LRR region of $\mathrm{N}^{\prime}$ is 50 amino acids longer than those of the L proteins. These findings support the idea that $\mathrm{L}^{3}$ and $\mathrm{N}^{\prime}$ may be structurally different.

Third, mutational analysis of the C-terminal regions of $\mathrm{N}^{\prime}$ and $\mathrm{L}^{3}$ revealed that the regions fulfill quite different functions (Figs. 4 and 5). These results also indicate that different LRR subregions of the $\mathrm{N}^{\prime}$ and $\mathrm{L}$ proteins contribute to the recognition of their common Avr effectors. Perhaps different sequences or secondary or tertiary structures of $\mathrm{CP}$ are recognized by the $N^{\prime}$ and $L$ gene alleles, although a bundle of four $\alpha$ helices was reported to be important for recognition by both $\mathrm{R}$ proteins (Dardick et al. 1999).

Finally, differences in the $\mathrm{N}^{\prime}$ and $\mathrm{L}^{3}$ proteins in their modes of pathogen recognition are supported by different patterns in emergence of resistance-breaking virus variants. The tobamovirus recognition spectrum of $\mathrm{N}^{\prime}$ does not follow the hierarchical interactions between $L$ gene alleles and Tobamovirus spp. PMMoV pathotypes $\mathrm{P}_{1,2,3}$ and $\mathrm{P}_{1,2,3,4}$ differ from pathotype $\mathrm{P}_{1,2}$ in one or two amino acids in the CP. $\mathrm{L}^{3}$ and $\mathrm{L}^{4}$ are overcome by both and the latter, respectively; however, $\mathrm{N}^{\prime}$ is effective against any pathotypes of PMMoV. In contrast, a single amino acid substitution enables an avirulent variant of TMV $\mathrm{CP}$ to escape $\mathrm{N}^{\prime}$ recognition because $\mathrm{N}^{\prime}$ can confer a resistance response to single amino acid substitution mutant $\mathrm{CP}$ of TMV (Taraporewala and Culver 1996). Although the $L$ gene alleles are not durable against PMMoV, $L$ genes are known to be durable $R$ genes against TMV (i.e., no $L$ gene-breaking TMV has been identified to date) (Janzac et al. 2009). Given that the $\mathrm{N}^{\prime}$ and $\mathrm{L}$ proteins share some $\mathrm{CP}$ structures for recognition, these $R$ gene proteins should respond in the same way to $\mathrm{CP}$ mutations; however, this is not the case. Taken together, it is most likely that $\mathrm{N}^{\prime}$ and $\mathrm{L}^{3}$ have functionally differentiated during evolution.

At the beginning of this study, we hypothesized that the $N^{\prime}$ gene would be an ortholog of the $L$ gene because these two $R$ genes confer resistance to Tobamovirus spp. and share structural similarities. However, phylogenetic analysis suggested that the NB domain of $N^{\prime}$ is closer to $I 2$ and $R 3 a$ than to $L$, whereas the C-terminal half of the LRR domain of $N^{\prime}$ is closer to $L$ than to $I 2$ and $R 3 a$. The results suggest that the $N^{\prime}$ and $L$ alleles have evolved through a complex pathway that likely includes multiplication and diversification of an ancestral gene and recombination or gene conversion. Although the evolution 
of the $N^{\prime}$ and $L$ alleles remains to be studied in detail, it is highly unlikely that the $N^{\prime}$ and $L$ alleles evolved by convergence. Moreover, chimera analysis of $N^{\prime}$ with $L^{3}$ and comparative mutational analysis revealed that the LRR domains of $\mathrm{N}^{\prime}$ and $\mathrm{L}^{3}$ have functionally differentiated during evolution. Therefore, it is unclear whether the $N^{\prime}$ and $L$ alleles are orthologs. At present, we have little information on the relationship between $N^{\prime}$ and $L$ because we isolated $N^{\prime}$ by a homology-based method and not through linkage analysis. There are two clues that would help clarify the genetic relationship between $N^{\prime}$ and $L$ and reveal the evolutionary processes leading to their divergence. One is to identify the $N^{\prime}$ locus in the $N$. sylvestris genome to determine if there is synteny with the Capsicum $L$ loci. Another is to identify other Tobamovirus $R$ genes that recognize the same pathogen effector from different genera of Solanaceae and compare them with $N^{\prime}$ and $L$. One Tobamovirus $R$ gene has been reported in eggplant (Dardick and Culver 1997).

In this study, we molecularly identified the $N^{\prime}$ gene, which has long been known and well studied but had not been cloned. We report here that $N^{\prime}$ is structurally close to the $L$ gene alleles but differs in its structural requirements for pathogen recognition. Further comparative analysis of these R proteins will lead us toward understanding the precise mechanisms underlying pathogen recognition by plants in ETI.

\section{MATERIALS AND METHODS}

\section{Plants and viruses.}

Nicotiana plants were grown in pots containing a commercial soil mixture (Sakata Seed Co., Yokohama, Japan) in a glasshouse at $25 \pm 5^{\circ} \mathrm{C}$. After agroinfiltration, the plants were transferred to growth chambers and conditioned under a $22^{\circ} \mathrm{C}$ cycle of 16-h days and 8-h nights. The tobamoviruses and CP genes used in this study are shown in Table 1. TMV was isolated from a commercial field of sweet pepper in Kochi Prefecture, Japan, characterized as TMV under standard procedures, and confirmed to be TMV by CP gene sequencing.

\section{Transient expression assay.}

Plasmid construction for a transient expression assay is described in Supplementary Methods. The plasmids for the expression of $\mathrm{R}$ proteins were transformed into Agrobacterium tumefaciens LBA4404. Agroinfiltrations were conducted as described before (Tomita et al. 2011). The tobamovirus CP were expressed alone by pGT vector or expressed within virus genome by pBTPIW vector (Tomita et al. 2011). Green fluorescent protein (GFP) was expressed by pBTPIW vector as a control and Tomato bushy stunt virus p19 was expressed using the 35S:p19 construct (Voinnet et al. 2003). N. benthamiana leaves were agroinfiltrated (absorbance at $600 \mathrm{~nm}\left[\mathrm{~A}_{600}\right]=0.5$ for $R$ gene constructs and $\mathrm{A}_{600}=0.1$ for $\mathrm{CP} /$ virus and $\mathrm{p} 19$ ) and then harvested at 3 to 5 days postinfiltration.

\section{Electrolyte leakage measurement.}

Electrolyte leakage was measured as previously described (Tomita et al. 2011). Three independent leaves were used for each measurement and the measurements were repeated three times for the transient expression of each $\mathrm{R}$ protein, with representative data. Statistical analysis was performed with Student's $t$ test.

\section{Detection of virus infection.}

Press blotting was performed as described previously (Hamada et al. 2007) using anti-ToMV, anti-PaMMV, antiPMMoV, or anti-TMV antisera (Japan Plant Protection Association, Tokyo). To assess the tobamovirus resistance in N. taba- cum plants, fully expanded leaves of 6-week-old plants were mechanically inoculated with purified virus particles at 10 $\mu \mathrm{g} / \mathrm{ml}$ as previously described (Tomita et al. 2011).

\section{Western blot analysis.}

Virus CP were detected by immunoblotting according to Taraporewala and Culver (1996) using anti-ToMV, antiPaMMV, anti-PMMoV, or anti-TMV antisera. Transiently expressed HA-tagged proteins were detected by immunoblotting as described previously (Sekine et al. 2008). For SDS polyacrylamide gel electrophoresis (PAGE) to separate HA-tagged $\mathrm{R}$ proteins, NuPAGE Novex 3 to $8 \%$ Tris-Acetate Gels (Life Technologies, Carlsbad, CA, U.S.A.) were used. As an internal control, post-transfer membranes were stained with $0.1 \%$ Amido Black in $45 \%$ methanol and $10 \%$ acetic acid followed by destaining in $90 \%$ methanol and $2 \%$ acetic acid, and the bands of the RubisCO large subunit were photographed.

\section{ACKNOWLEDGMENTS}

This work was supported in part by the Iwate Prefecture government, Ehime University and a Grant-in-Aid for Scientific Research (B) number 21380032 from the Japan Society for the Promotion of Science to K. Kobayashi. We thank K. Obara for technical assistance.

\section{LITERATURE CITED}

Albrecht, M., and Takken, F. L. 2006. Update on the domain architectures of NLRs and R proteins. Biochem. Biophys. Res. Commun. 339:459462.

Antignus, Y., Lachman, O., Pearlsman, M., Maslenin, L., and Rosner, A. 2008. A new pathotype of Pepper mild mottle virus (PMMoV) overcomes the $L^{4}$ resistance genotype of pepper cultivars. Plant Dis. 92:1033-1037.

Ashfield, T., Ong, L. E., Nobuta, K., Schneider, C. M., and Innes, R. W. 2004. Convergent evolution of disease resistance gene specificity in two flowering plant families. Plant Cell 16:309-318.

Banerjee, D., Zhang, X., and Bent, A. F. 2001. The leucine-rich repeat domain can determine effective interaction between RPS2 and other host factors in Arabidopsis RPS2-mediated disease resistance. Genetics 158:439-450.

Berzal-Herranz, A., de la Cruz, A., Tenllado, F., Diaz-Ruiz, J. R., Lopez, L., Sanz, A. I., Vaquero, C., Serra, M. T., and Garcia-Luque, I. 1995 The Capsicum $L^{3}$ gene-mediated resistance against the tobamoviruses is elicited by the coat protein. Virology 209:498-505.

Bhullar, N. K., Street, K., Mackay, M., Yahiaoui, N., and Keller, B. 2009. Unlocking wheat genetic resources for the molecular identification of previously undescribed functional alleles at the $P m 3$ resistance locus. Proc. Natl. Acad. Sci. U.S.A. 106:9519-9524.

Bhullar, N. K., Zhang, Z., Wicker, T., and Keller, B. 2010. Wheat gene bank accessions as a source of new alleles of the powdery mildew resistance gene Pm3: A large scale allele mining project. BMC Plant Biol. 10:88.

Boukema, I. W. 1980. Allelism of genes controlling resistance to TMV in Capsicum L. Euphytica 29:433-439.

Boukema, I. W. 1982. Resistance to a new strain of TMV in Capsicum chacoense Hunz. Capsicum Newsl. 1:49-51.

Boukema, I. W. 1984. Resistance to TMV in Capsicum chacoense Hunz. is governed by allele of the $L$-locus. Capsicum Newsl. 3:47-48.

Collier, S. M., and Moffett, P. 2009. NB-LRRs work a "bait and switch" on pathogens. Trends Plant Sci. 14:521-529.

Cooley, M. B., Pathirana, S., Wu, H. J., Kachroo, P., and Klessig, D. F. 2000. Members of the Arabidopsis HRT/RPPS family of resistance genes confer resistance to both viral and oomycete pathogens. Plant Cell 12:663-676.

Couch, B. C., Spangler, R., Ramos, C., and May, G. 2006. Pervasive purifying selection characterizes the evolution of $I 2$ homologs. Mol. PlantMicrobe Interact. 19:288-303.

Culver, J. N. 2002. Tobacco mosaic virus assembly and disassembly: Determinants in pathogenicity and resistance. Annu. Rev. Phytopathol 40:287-308.

Culver, J. N., and Dawson, W. O. 1989. Tobacco mosaic virus coat protein: An elicitor of the hypersensitive reaction but not required for the development of mosaic symptoms in Nicotiana sylvestris. Virology 173:755758. 
Dangl, J. L., Ritter, C., Gibbon, M. J., Mur, L. A., Wood, J. R., Goss, S. Mansfield, J., Taylor, J. D., and Vivian, A. 1992. Functional homologs of the Arabidopsis RPM1 disease resistance gene in bean and pea. Plant Cell 4:1359-1369.

Dardick, C. D., and Culver, J. N. 1997. Tobamovirus coat proteins: Elicitors of the hypersensitive response in Solanum melongena (eggplant). Mol. Plant-Microbe Interact. 10:776-778.

Dardick, C. D., Taraporewala, Z., Lu, B., and Culver, J. N. 1999. Comparison of tobamovirus coat protein structural features that affect elicitor activity in pepper, eggplant, and tobacco. Mol. Plant-Microbe Interact. $12: 247-251$

de la Cruz, A., Lopez, L., Tenllado, F., Diaz-Ruiz, J. R., Sanz, A.I., Vaquero, C., Serra, M. T., and Garcia-Luque, I. 1997. The coat protein is required for the elicitation of the Capsicum $L^{2}$ gene-mediated resistance against the tobamoviruses. Mol. Plant-Microbe Interact. 10:107-113.

Dodds, P. N., Lawrence, G. J., and Ellis, J. G. 2001. Six amino acid changes confined to the leucine-rich repeat beta-strand/beta-turn motif determine the difference between the $P$ and $P 2$ rust resistance specificities in flax. Plant Cell 13:163-178.

Ellis, J., Dodds, P., and Pryor, T. 2000. Structure, function and evolution of plant disease resistance genes. Curr. Opin. Plant Biol. 3:278-284.

Erickson, F. L., Holzberg, S., Calderon-Urrea, A., Handley, V., Axtell, M., Corr, C., and Baker, B. 1999. The helicase domain of the TMV replicase proteins induces the $N$-mediated defence response in tobacco. Plant J. 18:67-75.

Flor, H. H. 1971. Current status of the gene-for-gene concept. Annu. Rev. Phytopathol. 9:275-298.

Gao, J.-S., Sasaki, N., Kanegae, H., Konagaya, K.-I., Takizawa, K., Hayashi, N., Okano, Y., Kasahara, M., Matsushita, Y., and Nyunoya, H. 2007. The TIR-NBS but not LRR domains of two novel N-like proteins are functionally competent to induce the elicitor p50-dependent hypersensitive response. Physiol. Mol. Plant pathol. 71:78-87.

Garcia-Luque, I., Ferrero, M. L., Rodriquez, J. M., Alonso, E., de la Cruz, A., Sanz, A. I., Vaquero, C., Serra, M. T., and Diaz-Ruiz, J. R. 1993. The nucleotide sequence of the coat protein genes and $3^{\prime}$ non-coding regions of two resistance-breaking tobamoviruses in pepper shows that they are different viruses. Arch. Virol. 131:75-88.

Genda, Y., Kanda, A., Hamada, H., Sato, K., Ohnishi, J., and Tsuda, S. 2007. Two amino acid substitutions in the coat protein of Pepper mild mottle virus are responsible for overcoming the $L^{4}$ gene-mediated resistance in Capsicum spp. Phytopathology 97:787-793.

Gilardi, P., García-Luque, I., and Serra, M. T. 1998. Pepper mild mottle virus coat protein alone can elicit the Capsicum spp. $L^{3}$ gene mediated resistance. Mol. Plant-Microbe Interact. 11:1253-1257.

Gilardi, P., Garcia-Luque, I., and Serra, M. T. 2004. The coat protein of tobamovirus acts as elicitor of both $L^{2}$ and $L^{4}$ gene-mediated resistance in Capsicum. J. Gen. Virol. 85:2077-2085.

Gordon, K., Pfeiffer, P., Fütterer, J., and Hohn, T. 1988. In vitro expression of cauliflower mosaic virus genes. EMBO (Eur. Mol. Biol. Organ.) J. 7:309-317.

Hamada, H., Takeuchi, S., Morita, Y., Sawada, H., Kiba, A., and Hikichi, Y. 2003. Characterization of Paprika mild mottle virus first isolated in Japan. J. Gen. Plant Pathol. 69:199-204.

Hamada, H., Tomita, R., Iwadate, Y., Kobayashi, K., Munemura, I., Takeuchi, S., Hikichi, Y., and Suzuki, K. 2007. Cooperative effect of two amino acid mutations in the coat protein of Pepper mild mottle virus overcomes $L^{3}$-mediated resistance in Capsicum plants. Virus Genes 34:205-214.

Heath, M. C. 2000. Hypersensitive response-related death. Plant Mol. Biol. 44:321-334.

Huang, S., van der Vossen, E. A., Kuang, H., Vleeshouwers, V. G., Zhang, N., Borm, T. J., van Eck, H. J., Baker, B., Jacobsen, E., and Visser, R. G. 2005. Comparative genomics enabled the isolation of the $R 3 a$ late blight resistance gene in potato. Plant J. 42:251-261.

Innes, R. W., Bisgrove, S. R., Smith, N. M., Bent, A. F., Staskawicz, B. J., and Liu, Y. C. 1993. Identification of a disease resistance locus in Arabidopsis that is functionally homologous to the RPG1 locus of soybean. Plant J. 4:813-820.

Janzac, B., Fabre, F., Palloix, A., and Moury, B. 2009. Constraints on evolution of virus avirulence factors predict the durability of corresponding plant resistances. Mol. Plant Pathol. 10:599-610.

Jones, J. D., and Dangl, J. L. 2006. The plant immune system. Nature 444:323-329

Jordan, T., Seeholzer, S., Schwizer, S., Toller, A., Somssich, I. E., and Keller, B. 2011. The wheat Mla homologue TmMlal exhibits an evolutionarily conserved function against powdery mildew in both wheat and barley. Plant J. 65:610-621.

Kobe, B., and Kajava, A. V. 2001. The leucine-rich repeat as a protein recognition motif. Curr. Opin. Struct. Biol. 11:725-732.
Lanfermeijer, F. C., Dijkhuis, J., Sturre, M. J., de Haan, P., and Hille, J. 2003. Cloning and characterization of the durable tomato mosaic virus resistance gene $T m-2^{2}$ from Lycopersicon esculentum. Plant Mol. Biol. 52:1037-1049.

Lanfermeijer, F. C., Warmink, J., and Hille, J. 2005. The products of the broken $T m-2$ and the durable $T m-2^{2}$ resistance genes from tomato differ in four amino acids. J. Exp. Bot. 56:2925-2933.

McDowell, J. M., Dhandaydham, M., Long, T. A., Aarts, M. G., Goff, S. Holub, E. B., and Dangl, J. L. 1998. Intragenic recombination and diversifying selection contribute to the evolution of downy mildew resistance at the RPP8 locus of Arabidopsis. Plant Cell 10:1861-1874.

McHale, L., Tan, X., Koehl, P., and Michelmore, R. W. 2006. Plant NBSLRR proteins: Adaptable guards. Genome Biol. 7:212.

Meshi, T., Ishikawa, M., Motoyoshi, F., Semba, K., and Okada, Y. 1986. In vitro transcription of infectious RNAs from full-length cDNAs of tobacco mosaic virus. Proc. Natl. Acad. Sci. U.S.A. 83:5043-5043.

Meshi, T., Motoyoshi, F., Maeda, T., Yoshiwoka, S., Watanabe, H., and Okada, Y. 1989. Mutations in the tobacco mosaic virus $30-\mathrm{kD}$ protein gene overcome Tm-2 resistance in tomato. Plant Cell 1:515-522.

Moffett, P. 2009. Mechanisms of recognition in dominant $R$ gene mediated resistance. Adv. Virus Res. 75:1-33.

Moffett, P., Farnham, G., Peart, J., and Baulcombe, D. C. 2002. Interaction between domains of a plant NBS-LRR protein in disease resistancerelated cell death. EMBO (Eur. Mol. Biol. Organ.) J. 21:4511-4519.

Rairdan, G. J., and Moffett, P. 2006. Distinct domains in the ARC region of the potato resistance protein Rx mediate LRR binding and inhibition of activation. Plant Cell 18:2082-2093.

Ronald, P. C., Salmeron, J. M., Carland, F. M., and Staskawicz, B. J. 1992 The cloned avirulence gene avrPto induces disease resistance in tomato cultivars containing the Pto resistance gene. J. Bacteriol. 174:16041611

Saito, T., Hosokawa, D., Meshi, T., and Okada, Y. 1987. Immunocytochemical localization of the $130 \mathrm{~K}$ and $180 \mathrm{~K}$ proteins (putative replicase components) of tobacco mosaic virus. Virology 160:477-481.

Saito, T., Yamanaka, K., Watanabe, Y., Takamatsu, N., Meshi, T., and Okada, Y. 1989. Mutational analysis of the coat protein gene of tobacco mosaic virus in relation to hypersensitive response in tobacco plants with the $N^{\prime}$ gene. Virology 173:11-20.

Sakamoto, M., Tomita, R., Hamada, H., Iwadate, Y., Munemura, I., and Kobayashi, K. 2008. A primer-introduced restriction analysis-PCRbased method to analyse Pepper mild mottle virus populations in plants and field soil with respect to virus mutations that break $L^{3}$ gene-mediated resistance of Capsicum plants. Plant Pathol. 57:823-833

Sekine, K. T., Kawakami, S., Hase, S., Kubota, M., Ichinose, Y., Shah, J., Kang, H. G., Klessig, D. F., and Takahashi, H. 2008. High level expression of a virus resistance gene, $R C Y 1$, confers extreme resistance to Cucumber mosaic virus in Arabidopsis thaliana. Mol. Plant-Microbe Interact. 21:1398-1407.

Shen, Q. H., Zhou, F., Bieri, S., Haizel, T., Shirasu, K., and SchulzeLefert, P. 2003. Recognition specificity and RAR1/SGT1 dependence in barley Mla disease resistance genes to the powdery mildew fungus. Plant Cell 15:732-744.

Simonich, M. T., and Innes, R. W. 1995. A disease resistance gene in Arabidopsis with specificity for the avrPph3 gene of Pseudomonas syringae pv. phaseolicola. Mol. Plant-Microbe Interact. 8:637-640.

Simons, G., Groenendijk, J., Wijbrandi, J., Reijans, M., Groenen, J., Diergaarde, P., Van der Lee, T., Bleeker, M., Onstenk, J., de Both, M., Haring, M., Mes, J., Cornelissen, B., Zabeau, M., and Vos, P. 1998. Dissection of the Fusarium $I 2$ gene cluster in tomato reveals six homologs and one active gene copy. Plant Cell 10:1055-1068.

Takahashi, H., Miller, J., Nozaki, Y., Takeda, M., Shah, J., Hase, S., Ikegami, M., Ehara, Y., and Dinesh-Kumar, S.P. 2002. $R C Y 1$, an Arabidopsis thaliana RPP8/HRT family resistance gene, conferring resistance to cucumber mosaic virus requires salicylic acid, ethylene and a novel signal transduction mechanism. Plant J. 32:655-667.

Taraporewala, Z. F., and Culver, J. N. 1996. Identification of an elicitor active site within the three-dimensional structure of the tobacco mosaic tobamovirus coat protein. Plant Cell 8:169-178.

Tomita, R., Sekine, K. T., Mizumoto, H., Sakamoto, M., Murai, J., Kiba, A., Hikichi, Y., Suzuki, K., and Kobayashi, K. 2011. Genetic basis for the hierarchical interaction between Tobamovirus spp. and $L$ resistance gene alleles from different pepper species. Mol. Plant-Microbe Interact 24:108-117.

Tsuda, S., Kirita, M., and Watanabe, Y. 1998. Characterization of a pepper mild mottle tobamovirus strain capable of overcoming the $L^{3}$ genemediated resistance, distinct from the resistance-breaking Italian isolate. Mol. Plant-Microbe Interact. 11:327-331.

van der Biezen, E. A., and Jones, J. D. 1998. The NB-ARC domain: A novel signalling motif shared by plant resistance gene products and regulators of cell death in animals. Curr. Biol. 8:R226-227. 
Voinnet, O., Rivas, S., Mestre, P., and Baulcombe, D. 2003. An enhanced transient expression system in plants based on suppression of gene silencing by the p19 protein of tomato bushy stunt virus. Plant J. 33:949-956

Wang, M., Allefs, S., van den Berg, R. G., Vleeshouwers, V. G., van der Vossen, E. A., and Vosman, B. 2008. Allele mining in Solanum: Conserved homologues of Rpi-blbl are identified in Solanum stoloniferum. Theor. Appl. Genet. 116:933-943.

Weber, H., and Pfitzner, A. J. 1998. Tm- $2^{2}$ resistance in tomato requires recognition of the carboxy terminus of the movement protein of tomato mosaic virus. Mol. Plant-Microbe Interact. 11:498-503.

Whalen, M. C., Innes, R. W., Bent, A. F., and Staskawicz, B. J. 1991. Identification of Pseudomonas syringae pathogens of Arabidopsis and a bacterial locus determining avirulence on both Arabidopsis and soybean. Plant Cell 3:49-59.

Whitham, S., Dinesh-Kumar, S.P., Choi, D., Hehl, R., Corr, C., and Baker, B. 1994. The product of the tobacco mosaic virus resistance gene $N$ : Similarity to toll and the interleukin-1 receptor. Cell 78:1101-1115. 